\title{
Regional Security Institutions and Weak States: The Case of Post-Conflict Somalia and the Inter-Governmental Authority on Development (IGAD)
}

\author{
Safia Abukar Farole* \\ April 2018 \\ (Comparative Strategy, forthcoming)
}

\begin{abstract}
How do weak states in conflict-prone regions of the world manage crisis? This article applies a theory of international organizations as a framework to analyze how states in East Africa cooperated to address the problems associated with state collapse in Somalia. Based on a case study of the Inter-Governmental Authority on Development (IGAD), the study identifies unique factors for why weak states act through security organizations by focusing on the role of changing norms and structural factors. Finally, the article pinpoints factors that undermine the IGAD's ability to live up to its full potential, and offers potential policy remedies.
\end{abstract}

Keywords: IGAD, conflict management, Somalia, regional security, civil war

*Department of Political Science, University of California, Los Angeles

Contact: Safia Farole safiaf@ucla.edu

The author thanks Edmond Keller and Deborah Larson for their helpful comments on earlier drafts of this paper. 
Many regions in the world face the problem of a "bad neighborhood," and states often engage in collective efforts to confront threats to internal as well as regional security. With the end of the Cold War, the developing world has seen a decline in Great Power security guarantees, and as a result, one significant development has been the emergence of sub-regional alliances designed to collectively manage actual or potential spillovers from domestic conflicts experienced by one or more of its members (Ispahani 1984). For the past two decades in East Africa, the most pressing threat to regional stability has been state collapse in Somalia. In the aftermath of the civil war in Somalia in the early 1990s, countries in the Horn of Africa sub-region were faced with a dilemma, as the conflict in Somalia spilled into their border and threatened their domestic security. In light of this situation, states in the region attempted to create a viable collective security arrangement to address the region's security problems.

This article addresses the following question: under what conditions do weak states create and act through sub-regional institutions in order to collectively manage crises? To explore this puzzle, the paper adapts Abbott and Snidal's (1998) theory of international organizations (IOs), which attempts to explain why states act through formal international institutions. According to Abbott and Snidal, states create IOs in order to overcome coordination issues and to make cooperation over issue areas more efficient. Using an approach that integrates both rationalist and constructivist theories on international organizations, Abbott and Snidal argue that the main distinguishing functions of IOs are centralization and independence, and that these two characteristics are what lead states to act through these institutions. Abbott and Snidal's theory points to the relevance and power of IOs in the international system, and while they do not go as 
far as to argue that IOs will supplant the state in addressing conflict, their theory presents a useful contribution to our understanding of why states utilize IOs, and the features of these organizations that make them meaningful actors on the international stage.

As one of the most protracted cases of civil war, post-conflict Somalia offers an opportunity to examine the role regional actors played in the post-civil war era. After the collapse of the Siad Barre regime in 1991, various clans in Somalia vied for control over territory and resources, often resorting to revenge-seeking tactics that plunged Somali society further into a state of anarchy and chaos (Lyons \& Samatar 1995). Initially, internal conflicts remained confined to the former Somali Republic, but over time, given the fact that Somali ethnic kin resided in neighboring countries and that the borders between Somalia and its neighbors became more porous than ever before, conflicts spilled into neighboring states.

The literature on regional security institutions in East Africa is underdeveloped. Moreover, what little has been written is a-theoretical, so that it does not fit within the neorealist, neoliberal, or constructivist paradigms, despite the availability in the International Relations field of several competing theories on the relevance and importance of international organizations. ${ }^{1}$ The neorealist perspective calls into question the capacity of international organizations to shape regional order because an underlying assumption of realism is that small and weak states in the international system lack the ability to ensure international order and must depend on the resources and leadership of a hegemon. Thus, for neorealists IOs are a function of state power, and strong states utilize

\footnotetext{
${ }^{1}$ A common critique of International Relations literature by Africanists is that IR theory, in particularly realism treats Africa as irrelevant. While no one theory is capable of explaining a single case study, this paper proceeds under the assumption that Abbott and Snidal's (1998) theory of international organizations is also applicable to the African context. For a more detailed discussion on Africa in IR theory see Brown (2006).
} 
these organizations to achieve their objectives. Neoliberal institutionalists, who embrace the fact that IOs are a useful mechanism for facilitating cooperation between states, accept the neorealist assumption that international institutions are a reflection of state power and that they are affected by the distribution of power in the international system (Keohane \& Martin 1995). The main theoretical challenge to both the neorealist and neoliberal approaches on IOs is the constructivist school, which unlike neorealism and neoliberalism, argues that institutions can shape and impact state interests, and that state interests actually emerge from a process of interaction and socialization with IOs (Acharya 2009). Thus, the constructivist school takes a sociological rather than a rational or strategic approach to the study of international organizations to explain how states relate to these actors. Although Abbott and Snidal's theory of IOs hinges on predominantly rationalist assumptions, this article does not embrace a single theoretical approach.

This article applies a theoretical framework based on Abbott and Snidal's theory of international organizations to a case study of why East African states created the InterGovernmental Authority on Development (IGAD), and how these states have utilized this international organization in order to manage regional security issues broadly, and in particular the problems resulting from post-state collapse in Somalia. Consistent with Abbott and Snidal's theory, the evidence suggests that part of the reason why East African states utilized IGAD to collectively address the region's security problems, and in particular the Somali crisis, is because the organization provides a centralizing function and it acts as an independent and neutral actor. 
While Abbott and Snidal's theory provides a foundation to analyze why IGAD is a significant regional actor, this case study will be used to expand on their theory by identifying how the evolution of norms and structural factors also explains why states cooperate through international organizations. Although Abbott and Snidal purport to synthesize realist and constructivist narratives on international organizations, a limitation in their argument is that they overlook the effect of norms and systemic pressures on states' decision to act through institutions. Thus, this article contributes to the literature on regional security regimes by using the case of IGAD and post-state collapse Somalia to identify three reasons why weak states cooperate through international organizations: 1) a broadened understanding of the concept of security, 2) the current absence of superpower rivalry in the region and throughout the world, and 3) international pressure to address the Somali crisis while at the same time addressing the escalating threat of international terrorism. The analysis shows that independent of a regional hegemon, weak states can cooperate on their own to address regional security problems, and although the assistance of powerful external actors is helpful, it is not a necessary condition for states to initiate this cooperation.

While Abbott and Snidal's theory does not focus on what causes IOs to malfunction, understanding what makes IOs an effective channel of collective action also requires insight into what undermines it. Particularly, given the nascent ascendancy of IGAD's role in the region, this paper explores three factors that present a challenge to the organization's complete success in addressing the Somali crisis: 1) the lack of capacity for enforcement of agreements; 2) member states violating IGAD's mandate of noninterference by unilaterally intervening in Somalia; and 3) the disruptive effect that 
US counterterrorism policy in the sub-region presents for the success of an indigenous regional security architecture.

The findings from this study contribute to a better understanding of regional responses to containing conflict in a post-Cold War world order, particularly in countries in Third World regions, which include areas that have been under-theorized in the International Relations literature (Acharya 2011; Tickner 2003). Given that the problem of weak and failed states persists in the international system, it is important to understand how states utilize regional institutions to address this problem and to assess the effectiveness of reconstruction and nation-building efforts that these organizations undertake. Institutions are transforming state interactions in Africa and providing a mechanism to effectively address the continents security problems. And in particular, assessing the successes and failures of regional responses to the breakdown of the Somali state will be of critical importance for international actors seeking to design effective interventions targeting political, social, and human development efforts in Somalia, and in other developing countries.

The paper is divided into four sections, and a conclusion. Section One provides an overview of the role of regional institutions in dealing with conflict in developing parts of the world, and specifically Africa. Section Two more fully lays out Abbott and Snidal's theory of international organizations. While highlighting the limitations of Abbott and Snidal's theory, section Three expands on this theoretical framework and examines alternative factors to explain why East African states created IGAD. It examines the strategic concerns of the member states of IGAD in the expansion of the role of the organization from a strictly humanitarian and economic organization to a more 
political approach to collective security. In recent years, as a consequence of the changing nature of the regional insecurity dilemma, the organization's security mandate has expanded. Thus, section Four provides a critical assessment of how effective IGAD has been in coping with the regional security problem presented by state collapse in Somalia. Section Five concludes.

\section{Regional Institutions in the Developing World}

In the context of what is today arguably a politically unipolar world order, since the end of the Cold War conflict management in the international system has become regionalized (Lake \& Morgan 1997; Buzan \& Wæer 2003; Stewart-Ingersoll \& Frazier 2012). Powers and Goertz identify a system-level change since 1989, in which the reliance on multilateral alliances is on the decline, and international institutions such as the UN and regional organizations are increasingly handling security operations, particularly in Africa (Powers \& Goertz). The authors argue that the decline in military threat-balancing alliances is linked to the difficulty of achieving victory in civil and international wars. As a result, international institutions have become more active in peace-keeping and conflict resolution. Moreover, since the end of the Cold War, the traditional understanding of security, defined as the defense capabilities and policies of states against external threats, has been expanded to include "human security" (Pettiford 1996; Thomas 2003). Given that a majority of militarized disputes occur in less developed parts of the world, the notion of security has been broadened to include threats such as famine, disease, and environmental contamination, which are found at the internal, regional, transnational, and international levels (Thomas 2003). 
While states in developed regions of the world have a stronger record of cooperating on security problems, regional security cooperation in the developing world remains at a nascent stage. Given that the incidence of intrastate conflicts is greater than the number of international wars in the post-Cold War world (Harbom \& Wallensteen 2005), the need for collective regional security institutions is even greater in Asia, Africa, and the Middle East - regions that are more prone to experiencing civil wars. Despite the fact that African security institutions have been slow to evolve, nonetheless, they have responded to the structural pressures stemming from the end of the Cold War and the withdrawal of superpower involvement by embracing international organizations as a viable mechanism to resolve the continent's widespread conflicts.

\section{Regional Institutions in Africa}

While the effort to construct a continent-wide security architecture in Africa has origins in the colonial period, the first major step toward the establishment of a collective regional security organization in independent Africa was the creation of the Organization of the African Unity (OAU) in 1963 (Franke 2008). The founding of the OAU served as a compromise between two groups of African leaders, one calling for an immediate centralization of military power, and the second group, which called for a more gradual approach (ibid). The Defense Commission, which served as the organization's main body for dealing with security matters, was tasked with harmonizing the defense policies of member states, however; the idea of institutionalizing security cooperation proved threatening for several member states, who saw this as an infringement on their sovereignty $(i b i d)$. While the lack of political will and institutional inadequacies 
hampered the effectiveness of the OAU, the incentive to breathe new life into Africa's cooperative security efforts gained greater traction with the end of the Cold War.

With the end of the super power rivalry, client states that had been stable under the bipolar system descended into protracted violence, fuelled in part by the weapons that had been supplied by their superpower patrons (Erickson 2007). Thus, the phasing out of the Cold War security architecture, and the ensuing unmediated domestic violence experienced by member states inspired a growing acknowledgment among African leaders that they needed to overcome the challenges that plagued previous attempts to foster inter-African security cooperation. While increased political and economic cooperative efforts among African states occurred in the early 1990s, Benedikt Franke argues that the tragedies that unfolded in Rwanda, Somalia, and the Democratic Republic of Congo during this period highlighted the consequence of regional disunity, and helped spark a movement of reform (Franke 2008). Many leaders now seemed ready to engage in contingent compromises and to make the strategic choice, at this critical moment, to commit to the idea of sub-regional security institutions.

A significant outcome of this renewed debate over closer inter-African security cooperation occurred in July 2002, when the 53 African heads of state voted for the replacement of the moribund OAU with the African Union (AU) (Franke 2008). Unlike the ineffective $\mathrm{OAU}$, in the $\mathrm{AU}$, the sovereignty of member states remains inviolable so long as they are able to protect their citizens (Møller 2009). However, if a member state violates the promise to fulfill this obligation, the AU has the authority to intervene within that state based on the decision of the AU Assembly, with a two-thirds majority. ${ }^{2}$ As a

\footnotetext{
${ }^{2}$ The Assembly is the African Union's most supreme authority; it consists of summits of heads of states and governments of member African states.
} 
further indication of the commitment to pursue closer security cooperation, the AU consists of institutional bodies specifically devoted to dealing with armed conflict and security issues, such as the Peace and Security Council, the Continental Early Warning System, and the African Standby Force (Franke 2008). Since its inception, the AU has engaged in peace-keeping missions in Burundi, Sudan, and Somalia, with some member states contributing troops. While the AU has a mixed track record of success in these interventions, an important part of its continued vitality remains its outsourcing of responsibility to sub-regional organizations, such as IGAD, which is the focus of this paper.

\section{Abbott and Snidal's Theory of International Organizations}

Abbott and Snidal's theory suggests that two functional characteristics of IOs lead states to act through these organizations as opposed to other forms of cooperation (such as decentralized cooperation, informal consultation, and treaties). The theory argues that the functions of centralization and independence make IOs a viable mechanism for interstate cooperation, and this increases the ability of states to act more efficiently to address conflict. The following section details these two components of Abbott and Snidal's theory. If the IGAD case study supports Abbott and Snidal's theory, the evidence should show that IGAD was an attractive vehicle for regional states because it provided centralizing functions, and that it is viewed as an independent body that can resolve regional disputes.

\section{Centralization}

In Abbott and Snidal's theory, centralization means that an international organization has an "established organizational structure and centralized administrative 
support that can render collective activities more efficient (Abbot \& Snidal 1998, pp. 10)." The ability of IOs to centralize interactions between states is beneficial for two reasons: centralization supports direct state interaction and it organizes the operational activities within an IO. IOs facilitate interactions between states because they serve as a stable mechanism for states to negotiate, and this, as a result, allows states to respond to events that develop suddenly (ibid pp. 9). And unlike informal or decentralized arrangements, this centralizing feature of IOs shapes how states interact with each other by providing a neutral and depoliticized forum of communication.

\section{Independence}

The second function that IOs serve is independence, which is the ability of an IO to act as an autonomous and neutral arbiter. A reputation for independence impacts the decision of states to act through IOs because doing so confers more legitimacy on collective or individual action. One property of IO independence is that it encourages direct state interaction. Because IOs are independent, they are not simply tools that states use to pursue their own self-interest. Instead, independent IOs drive cooperation among states because IOs also initiate efforts, and don't solely function as supportive organizations. In this sense, IOs are agenda-setters, and they call member states together to highlight pressing issues.

The neutrality of international organizations is a characteristic that allows them to mediate among member states in disputes. The fact that IOs act as a neutral party in a conflict between states underwrites the ability of IOs to undertake efforts in peacekeeping, peace-making, and peace-building. And a defining feature of IO neutrality is that it facilitates intervention, so that in order to overcome bargaining deadlocks, IOs can 
use mediation, conciliation, and fact-finding to resolve disputes that threaten the peace. While Abbott and Snidal recognize that IO neutrality can be curtailed by powerful states, these states are careful to compromise an IOs neutrality because the neutrality of an IO confers a degree of legitimacy to individual and collective actions that are undertaken under its auspices.

\section{Regional Solutions to Regional Security Problems? The Case of IGAD}

In the past several years, as an African regional organization, IGAD has been an active player in security issues pertaining to state-building and terrorism. To reach this point, it means that the East African states that comprise IGAD had to view themselves as having a common security interest, and the political will and capacity to embark upon a collective security effort to stabilize Somalia, which since the collapse of the state has long been a cauldron of regional instability. This paper argues that this collective effort to address regional security issues results from three major factors: 1) member states realizing that economic development is linked to regional security; 2) the absence of superpower rivalry in the region; and 3) the international political pressure to address the Somali crisis.

Realizing The Collective Benefit of Addressing Security Before Development.

IGAD was not originally designed to deal with issues relating to strategic security, but it has over time come to assume such a role. The Inter-Governmental Authority on Drought and Development (IGADD) was created in 1986, and at the time the seven member states - Djibouti, Ethiopia, Kenya, Somalia, Sudan, Uganda, ${ }^{3}$ were mainly concerned with tackling regional problems of drought, famine, and underdevelopment. Within five years

\footnotetext{
${ }^{3}$ In 1993 IGADD's membership expanded to seven when Eritrea gained independence from Ethiopia. Isaias Afewerki, who led the country's liberation effort was its first president.
} 
after the inception of IGADD, regime change swept through three of its member states, ${ }^{4}$ bringing into power heads of state that were keen on expanding IGADD's mission to include regional security, Ethiopia and Eritrea in particular. Along with president Museveni of Uganda, the new leadership in Ethiopia and Eritrea were frustrated by what they perceived to be the failure of the Organization of African Unity (OAU) to intervene in the intrastate conflicts that had claimed the lives of many in Uganda and Eritrea's civil wars, citing the mandate of non-interference (Healy 2011). Realizing that development problems are inextricably linked to regional security, it was at this strategic moment that the leadership of member states decided to expand IGADD's mission to include peace and security, and subsequently, the organization's name was changed to the InterGovernmental Authority on Development (IGAD).

The current eight members of this regional bloc are Djibouti, Eritrea, Ethiopia, Kenya, Somalia, South Sudan, Sudan, and Uganda (ISS 2004; Mulugeta 2009). The new IGAD places an emphasis on peace and security as the foundation for development in the region, and it focuses on three primary areas: conflict prevention, management, and resolution and humanitarian affairs; infrastructure (transport and communications) development; and food security and environment (1SS 1996). Within this revitalized framework member states agreed to a) respond collectively to eliminate threats to regional peace and stability; b) to create effective mechanisms of consultation and cooperation to settle disputes peacefully; and c) to find solutions to disputes between member states through the mediation mechanisms of IGAD before referring them to other regional or international organizations (ibid).

\footnotetext{
${ }^{4}$ In 1989 Omar al-Bashir took over power in Sudan; in 1991 Ethiopian People's Revolutionary Democratic Front (EPRDF) militarily overthrew Mengitsu Haile Miriam in Ethiopia; also, in 1991Siad Barre of Somalia was removed through a coup.
} 
These aspects of IGAD's mandate are consistent with the centralizing features of international organizations that Abbott and Snidal characterize in their theory. IGAD facilitates the ability of East African member states to cooperate on vital development issues, while at the same time providing a forum for these states to formally address disputes. Expanding on Abbott and Sindal's theory, norms also played an important role in the decision made by East African states to create IGAD. Specifically, changes in the norms concerning the issue of security encouraged regional members states to redefine IGAD's function.

By shifting IGAD's mandate to give greater priority to strategic as well as human security, IGAD member states came to adopt the view that any cooperation on development efforts would need to be preceded by stability within member states. In fact, the preexisting institutional framework on collective responses to development laid the foundation for cooperation on regional security issues. As Powers and Goertz (2006) argue, "when countries realized security and economic problems were linked regionally, they restructured their regional economic institutions [REIs] to deal with this linkage by adding security treaties and mechanisms to REI structures (Powers \& Goertz 2006).” Thus, upon realizing the benefit in addressing security issues collectively, East African states strategically reshaped IGAD's mandate, thus laying the groundwork for the organization's future leadership in regional peace-building efforts.

The Absence of Superpower Rivalry. The demise of the Cold War and the end of bipolarity is the second condition that facilitated an environment for regional security cooperation. During the Cold War, the Horn was an active battleground for superpower competition, where both powers aligned with Sudan, Ethiopia, and Somalia at different 
times (Woodward 2006). The subsequent détente between the US and the Soviet Union left the nations of the Horn without security guarantees from their superpower clients, contributing to the 1991 collapse of both the Mengistu regime in Ethiopia and the Siad Barre regime in Somalia. Not only did this structural change in the international environment contribute to the outbreak of protracted civil wars in former client states such as Somalia, but it also led to a proliferation of small arms throughout the region. With no superpower patrons left to keep their clients in check, it became more imperative to confront regional threats through the mechanisms provided by IGAD.

Although the shift in the global balance of power is not a sufficient factor in explaining how East African states came to create a collective security organization, this new reality lifted an impediment to regional cooperation. States in the region were no longer bound in a situation of dependency with a superpower patron. Furthermore, the diffusion of conflict that followed state collapse in Somalia made it clear that the domestic security of regional member states is contingent on regional stability.

International Pressure. Third, pressure from non-regional actors has also served as an impetus for East African states to cooperate in confronting the threats emanating from Somalia, which has implications for both regional and international security. The international actors with the greatest stake in a stable Horn region are various African and European governments, the United States, the African Union (AU), the European Union (EU), and the UN. Since the collapse of the state in Somalia, the predominate strategy of peace-building advocated and utilized by almost all international actors for stabilizing Somalia has been a top-down security approach. 
In the peace-building literature, scholars identify two types of peace-building approaches: a "top-down security" approach, which involves state-building through the reinstitution of a government using military and police forces; and "bottom-up stability" approach in which peace is achieved by obtaining a balance of power among conflicting indigenous forces (in the case of Somalia this is the clan system) (Burgess 2013). In the absence of the central government in Somalia during the two decades of state collapse, local communities had to provide their own security (Menkhaus 2007a). While the informal arrangement of local authorities managed to maintain a fragile peace, it precluded serious efforts to engage in state building, which was the priority for the international community. Enabling and assisting regional partners to restore state security in Somalia is a shared objective among policymakers in the international community because top-down stability in Somalia is seen as a necessary precondition to the democratic process. And especially in the post-9/11 world, due to the commonly evoked association made by American policymakers that weak states are fertile breeding grounds for terrorist activity (Patrick 2007), pursuing a policy of reviving a Somali state using hard power, as opposed to the soft power of grassroots organizing has gained greater traction. It should be noted that while international actors have favored a topdown approach to state-building in Somalia,

In the past decade, particularly with the rise of the terrorist organization AlShabaab, Somalia has become a growing security threat to the regional interests of international actors, who have worked with IGAD member states to combat Al-Shabaab and restore security in Somalia. While Islamist movements were beginning to form under Somalia during Siad Barre's regime, it was around early 2006 when their militancy began 
to noticeably take hold in the country (Menkhaus 2002). In 2006 the Union of Islamic Courts (UIC) took control of the Somali capital, Mogadishu and much of Southern Somalia. Their objectives were to establish sharia (strict fundamentalist) law throughout the country and to wage a jihad (holy war) against Ethiopia - Somalia's historical regional rival (Shinn 2003). The prospect of an Islamic government forming in Somalia alarmed the US as well as Ethiopia. And, Ethiopia, in part serving as a US proxy intervened in Somalia in 2007 and forced the UIC from Mogadishu (Menkhaus 2007b). The UIC, consisting of both moderate and radical elements, in 2009 splintered along religion-based ideological lines. The moderates joined the Transitional Federal Government (TFG), and the extremist strand of the UIC emerged into Al-Shabaab, a hardline group affiliated with Al Qaeda.

In all, since the terrorist attacks of September 11, 2001, the main objective of actors such as the US and the EU has been to support the AU and IGAD member states to reconstitute the Somali state in order to prevent Al Qaeda and other extremists groups from establishing a base there. Within the framework of the "global war on terror", the logic of top-down state building was initially applied by the United States in reconstituting the states of Afghanistan and Iraq. Despite the drawbacks that have accompanied the use of such a strategy in these states, the US simultaneously supported a top-down policy in Somalia, albeit with a smaller US military presence and through regional channels.

Beginning under the Bush administration, the US Department of Defense continues to undertake several military initiatives to train regional partner states in counterterrorism operations, and from 2007 to 2012650 million dollars in American 
funds has been directed toward training, equipping, and supporting East African forces in combat operations (Burgess 2013). Similarly, the European Union and the UN have funded the African Union and IGAD with hundreds of millions of dollars to implement a top-down security approach in Somalia. Along with supporting IGAD initiatives in the Somali peace process (Gibert 2006), since 2007 the EU has funded the African Union 575 million dollars in its Somalia peace-keeping operation and has funded the training of the new Somali national police force (Burgess 2013).

While external actors such as the EU and the US have a vested interest in a stable Somalia, by working through IGAD, they legitimize the institution, thereby encouraging regional member states to pursue collective measures to combat regional security threats. This, in turn, demonstrates that IGAD is an appealing forum of action for both regional and international actors because it carries the legitimacy of being an independent and neutral body, as Abbot and Snidal's theory would predict.

In sum, the evidence suggests that various international actors have applied pressure on IGAD member states to manage the security problems associated with Somali state collapse. While Abbott and Snidal's theory doesn't account for the effect of systemic factors such as shifts in the global distribution of power and external political pressure, this case study of East African institution building shows that these variables are important for understanding why weak states cooperate through international organizations.

\section{Assessing the Effectiveness of IGAD as an International Organization The Qualified Success of IGAD}


As an African-led regional organization, IGAD has been instrumental in pushing for regional solutions to confront the security challenges posed by Somali state collapse, as well as making strides towards reconstituting the Somali state. Although IGAD's institutional mandate authorizes measures for peace-keeping, peace-making, and peacebuilding, the organization's main contribution to the Somali peace process has been in the area of peace-making. In the fallout of the failed international interventions in Somalia in the early 1990s, and as agreed upon by member states in the organization's mandate, IGAD was successful in facilitating the Somali peace process. Beginning in the late 1990s, there were several initiatives to begin the Somali peace process and to install a viable government, but there were main two rival efforts to establish a transitional Somali government, each led by Ethiopia and Djibouti. ${ }^{5}$

Despite IGAD's post-conflict reconciliation successes, there are several factors that hinder the organization's ability to manage the security threats originating from Somalia. These factors are 1) the lack of a capacity for enforcement, 2) unilateral military action undertaken by member states, and 3) the unintended undermining effect of US counterterrorism policy in the region.

\section{The Lack of Capacity for Enforcement.}

With the proliferation of international organizations, and the rising trend toward resolving crises through regional security organizations, the major obstacle faced by these institutions, particularly in the developing world, is the ability to enforce agreements.

IGAD has no real enforcement mechanism to ensure that members comply with initiatives such as the Declaration on the Cessation of Hostilities. Instead, it has outsourced such responsibilities to the UN and the African Union. For example, in 2003

\footnotetext{
${ }^{5}$ For details on the rival peace processes see Healy (2011).
} 
the AU sent a reconnaissance mission to Somalia and endorsed a proposal calling on IGAD member states to comply with a UN arms embargo against Somalia (ISS 2003). Thus despite IGAD's declaration that "the anchor of all the efforts in relation to Somalia must be IGAD (ISS 2008)," the organization recognizes its limited ability to enforce security measures geared toward rehabilitating Somalia, and it relies on international organizations such as the AU, the UN, and member states to provide the resources and political support needed in the process.

\section{Member States Taking Unilateral Action to Intervene in Somalia}

In order for an international organization to be effective in managing regional conflict, member states should obey the institutional mechanisms within the organization designed to coordinate a collective response to crises. Although such a mechanism is enshrined in IGAD's mandate, in the past both Kenya and Ethiopia have undertaken unilateral efforts that undermine the legitimacy of IGAD to be an effective regional institutional actor.

In light of the growing security threat they face from Somalia, both Kenya and Ethiopia have recently conducted unilateral military operations inside Somalia. In response to a growing crescendo of Al-Shabaab cross-border attacks and kidnappings, on October 16, 2011, Kenya sent 2,000 troops across the border into Somalia to target AlShabaab bases. ${ }^{6}$ In justifying this incursion against a non-state actor, Kenya claimed that its action was in self-defense. Colonel Cyrus Oguna, the officer in charge of the Kenya military's Information and Operations said: “Our initial plan was to degrade the capacity

\footnotetext{
${ }^{6}$ For more details on the operation and the domestic political elements behind the invasion see (Prestholdt 2011). There is a dispute over whether the Somali Transitional Federal Government (TFG) was assisting the Kenyan operation, or if Kenya acted alone. Members from the TFG argue that Kenya only provided logistical and financial support.
} 
of the Al-Shabaab which is a major threat to the peace, economy, and stability of Kenya and the entire region and to restore normalcy in the war-ravaged country (The Star 2014).” While the evidence suggests that Kenya initiated this limited invasion independently, by October $21^{\text {st }}$ IGAD announced its support for this operation, thereby supporting Kenya's right to defend its territory from attacks by militants (IGAD 2011). Although the operation was successful in driving out Al-Shabaab from twenty towns in southern Somalia, it raises the questions about IGAD's leadership role in the area of peace-keeping. By sanctioning Kenya's unilateral action ex post facto, it seems as if IGAD is leading from behind. However, given that the organization's limited capacity to engage in peace-keeping (as evidenced by its authorization of using African Union troops in Somali peace-keeping operations), this reinforces the argument made in this paper that IGAD's organizational strong suit is in peace-making, and not peace-keeping.

Ethiopia, due to ongoing battles with Islamist militants inside its own territory, was a natural ally to the US in fighting the "War on Terror" in the Horn. And with the growing threat of having an Islamist government on its borders, on July 20, 2006, Ethiopia invaded and began occupying Somalia with the objective of propping up the Transitional Federal Government (TFG) (Menkhaus 2007). Meanwhile, there was also international concern about the growing power and influence of the Union of Islamic Courts (UIC) within Somalia, a broad-based group that ended warlord control of Mogadishu, and expanded its influence across central and southern Somalia. Thus, on December 6, 2006, the UN Security Council passed resolution 1725, allowing the UN to lift its arms sanctions on Somalia and to authorize the military forces of IGAD member states to intervene in the country (United Nations 2006). Despite the fact that this UN 
resolution legitimized the institutional capacity of IGAD, the fact that in the preceding months Ethiopia had unilaterally invaded Somalia demonstrates the disregard Ethiopia has for addressing legitimate security concerns in concert with IGAD. By the time Ethiopia ended its two-year occupation of Somalia in January 2009, the Islamists insurgency in Somalia had intensified and it gave birth to the radical al-Qaeda linked AlShabaab.

While both Kenya and Ethiopia's unilateral operations in Somalia raise questions about the institutional viability of IGAD as a mechanism to address regional conflict, it is possible that these states have grown frustrated with the institution and have decided to take matters into their own hands. However, the Ethiopian invasion shows that there are pitfalls involved in taking unilateral action in Somalia, because rather than quelling the insurgency, Ethiopia's invasion contributed to further radicalization of Somali militants, thus setting back IGAD's counterterrorism plan in the Horn.

\section{US Counterterrorism Policy}

Since the attacks of September 11, 2001, East Africa has come to occupy a central place in the US "War on Terror." Specifically, the region is the focus of two US counterterrorism initiatives in Africa: the East Africa Counterterrorism Initiative (EACTI) and the Combined Joint Task Force - Horn of Africa (CJTF-HOA) (Shinn 2005). These initiatives have helped to strengthen the military capacity of Kenya and Ethiopia to disrupt terrorist activity both within and outside of their borders, and given the claim that these operations have thwarted terrorist plots (Kagwanja 2006), this is a net positive for the region as whole. While this indirect strategy of involvement in the Horn has allowed the US to avoid introducing ground troops into the region, in the long-term, elements of 
the American counterterrorism campaign in this vital security region undermine the capability of regional institutions such as IGAD and the AU to take the initiative on combating regional threats to security. In particular, the growing American reliance on drones to root out Al-Shabaab in Somalia (Mazzetti \& Schmitt 2011), although effective in achieving American security interests, weakens the legitimacy of these regional security organizations. While the use of drones is associated with rising antiAmericanism in places such as Pakistan and Yemen, this strategy could serve to garner greater support for Al-Shabaab in Somalia. While eliminating Al-Qaeda linked operatives in the battlefield is a good short-term strategy, a lasting solution to quell radical militants is for the US to continue supporting both bottom-up and top-down peace-building efforts. Rather than acting unilaterally, the US should continue to strengthen the capacity of IGAD member states to conduct counterterrorism operations. By supporting regional efforts to combat security threats, the US can enhance the ability of IGAD to target terrorist groups operating in the region. In particular, this strategy can be effective with a militant group such as Al-Shabaab, which has a limited ability to strike outside its borders.

\section{Discussion and Conclusions}

After the period of state collapse in Somalia, the Inter-Governmental Authority on Development (IGAD) has functioned as an important actor in East Africa that has sought to pursue a unified regional diplomatic approach to this crisis. Several findings from this study confirm Abbott and Snidal's theory of international organizations. In particular,

member states created IGAD with the goal of facilitating cooperation on regional security problems. Also, IGAD's ability to centralize operations related to development and 
security and it's growing reputation as an independent actor in a region rife with warring factions have made this institution an appealing forum for both regional and external states. Furthermore, IGAD's capacity to serve as a neutral arbiter has led to its successful diplomatic interventions in the Somali peace process. IGAD's record of peace-making has been appropriately cited as being instrumental in the 2012 successful parliamentary and presidential elections in Somalia, which for the first time in years took place on Somali soil. Despite this milestone, peace and security remain fragile both inside and outside of Somalia, as a result of Al-Shabaab led terrorist operations.

By drawing on different schools of thought within the International Relations literature, Abbott and Snidal's theory provides a framework for explaining why states create and act through international institutions. While rationalist and constructivist explanations for the existence of international organizations have their limitations, Abbott and Snidal's focus on the function of IOs to explain their efficacy is a useful standard that can be used to measure the effectiveness of any international organization. However, when applied to the East African context, this case study indicates that Abbott and Snidal's theory must be expanded to take into consideration the unique forces at play in this volatile region. Thus, in regards to the implications for International Relations theory, this case study demonstrates that testing theories in non-Western contexts strengthens our understanding of why states create international organizations, and why these institutions are meaningful actors in the international system.

Despite the difficulties associated with creating and maintaining peace and security in such a conflict-prone region as East Africa, IGAD's previous successes in mediation provide signs of hope for the future. Among its major achievements, IGAD 
presided over the process of selecting a new central government for Somalia, and in 2005 it achieved a settlement between Northern and Southern Sudan, which paved a way for the people of South Sudan to vote for independence in 2011. While some analysts remain pessimistic about the prospects for IGAD's continued success (Healy 2011; Apuuli 2011; De Waal 2007; Khadiagala 2009), more legitimacy is being conferred upon the organization by the international community as a result of its agenda-setting role in coordinating international responses to regional conflict. IGAD has the potential to overcome the roadblocks to building a regional security architecture by focusing on what it does best - negotiating settlements between member states. Backed by the African Union and the UN, IGAD needs to develop greater autonomy and to distance itself from the power play that is rife among its member states. Rather than sidelining these issues, which have the potential to further destabilize the region, IGAD needs to expand its peace-making efforts, that way interference by member states into the other's affairs will be minimized and IGAD can shift its effort to peace-building. This would require a considerable commitment of material resources in the form of funding for social programs (e.g. health, education, welfare, etc.) and institution building. And given the fact that IGAD members tend to be resource poor, in the foreseeable future international organizations and bilateral donors should target their funding to this objective.

As the main regional stakeholders in Somalia's stability, it will become increasingly important for Kenya and Ethiopia to act in concert with IGAD as well as the Somali government to curb radical Islamists movements in the region and to devise a solution to the refugee crisis. IGAD is committed to organizing such an effort, however, 
Kenya, Ethiopia, and other IGAD member states must remain committed to engaging in cooperative solutions for the regions security problems.

While this case study provides insight into how weak states in the developing world cooperate to build regional institutions designed to address pressing security problems, further research is necessary to understand how IGAD coordinates these issues on the ground. Such studies would require field research conducted at the IGAD headquarters, and should include a survey of the organization's leadership in order to better understand the link between policy and practice. Furthermore, this case study highlights the need to have a clearer understanding of Kenya and Ethiopia's interventions inside Somalia. In future studies, this can be done by soliciting high-level interviews with officials within the Ethiopian and Kenyan government and military with knowledge of these operations. Supplementing case study work with empirical data will contribute to our understanding of what makes regional security institutions both effective and ineffective in underdeveloped and high conflict areas of the world. And given the ongoing incidents of civil war, which threaten to destabilize regions throughout Africa, the Middle East, and Asia, regional institutions might be considered a possibly viable mechanism for peace-building. 


\section{References}

Abbott, Kenneth W., and Duncan Snidal. 1998. "Why States Act Through Formal International Organizations." Journal of Conflict Resolution 42 (1): 3-32.

Acharya, Amitav. 2009. Constructing a Security Community in Southeast Asia: ASEAN and the Problem of Regional Order. London: Routledge.

- 2011. "Dialogue and Discovery: In Search of International Relations Theories Beyond the West." Millennium - Journal of International Studies 39 (3): 619-37.

Apuuli, Kasaija Phillip. 2011. "IGAD's Peace and Security Strategy." In Regional Security in the post-Cold War Horn of Africa, edited by Roboa Sharamo and Berouk Mesfin 1- 456.

Brown, William. 2006. "Africa and International Relations: A Comment on IR Theory, Anarchy and Statehood.” Review of International Studies 32 (1): 119-143.

Burgess, Stephen. 2013. "A Lost Cause Recouped: Peace Enforcement and State-Building in Somalia." Contemporary Security Policy 34 (2): 302-23.

Buzan, Barry, and Ole Wæer. 2003. Regions and Powers: The Structure of International Security. Cambridge University Press.

De Waal, A. 2007. "In Search of a Peace and Security Framework for East Africa." Paper presented at the Conference on the Current Peace and Security Challenges in the Horn of Africa, Addis Ababa, Ethiopia, March 12-13.

Erickson, J. 2007. "Regional Cooperation and Third World Security: The Case of Small Arms and Light Weapons." Paper presented at the Sixth Annual Pan-European International Relations Conference, Torino, Italy, September 2007.

Franke, Benedikt. 2008. “Africa's Evolving Security Architecture and the Concept of Multilayered Security Communities.” Cooperation and Conflict 43(3): 313-40.

Gibert, Marie. 2006. "The European Union in the IGAD-Subregion: Insights from Sudan \& Somalia." Review of African Political Economy 33(107): 142-50.

Harbom, Lotta, and Peter Wallensteen. 2005. "Armed Conflict and Its International Dimensions, 1946-2004." Journal of Peace Research 42 (5): 623-635.

Healy, Sally. 2011. "Seeking Peace and Security in East Africa: The Contribution of the InterGovernmental Authority on Development.” International Affairs 87 (1): 105-20.

Intergovernmental Authority on Development (IGAD). 2011. "Communiqué of the 41st ExtraOrdinary Session of the IGAD Council of Ministers, IGAD, October 21, 2011." Accessed May 25, 2013. http://igad.int/attachments/361_IGAD_41th_COM_Communique.pdf

Institute for Security Studies (ISS). 1996. "IGAD: Agreement Establishing the InterGovernmental Authority on Development." Accessed June 18, 2013. http://www.issafrica.org/uploads/AGREEMENTESTAB.PDF

Institute for Security Studies (ISS). 2003. "Strengthening the Role of IGAD in Regional Peace Initiatives and Post Conflict Reconstruction”. Accessed June 18, 2013. http://www.issafrica.org/pubs/CReports/IGADDec03/IGAD.pdf

Institute for Security Studies (ISS). 2004. "IGAD Profile.” Accessed May 20, 2013. http://www.iss.org.za/AF/RegOrg/unity_to_union/igadprof.htm

Institute of Security Studies (ISS). 2008. "The Declaration of the $13^{\text {th }}$ Extra-Ordinary Session of the IGAD Assembly of the Heads of State and Government." Accessed May 22, 2013. http://www.issafrica.org/uploads/IGAD13SOMALIA.PDF

Ispahani, Mahnaz Zehra. 1984. "Alone Together: Regional Security Arrangements in Southern Africa and the Arabian Gulf." International Security 8 (4): 152-75. 
Kagwanja, Peter. 2006. "Counter-Terrorism in East Africa: New Security Frontiers, Old Strategies.” African Security Studies 15(3): 72-86.

Keohane, Robert O., and Lisa L. Martin. 1995. "The Promise of Institutionalist Theory." International Security 20 (1): 39-51.

Khadiagala, Gilbert M. 2009. "Regionalism and Conflict Resolution: Lessons from the Kenyan Crisis." Journal of Contemporary African Studies 27 (3): 431-44.

Lake, David A., and Patrick M. Morgan. 1997. Regional Orders: Building Security in a New World. University Park: Penn State Press.

Lyons, Terrence P., and Ahmed Ismail Samatar. 1995. Somalia: State Collapse, Multilateral Intervention, and Strategies for Political Reconstruction. Washington, DC: Brookings Institution Press.

Mazzetti, Mark and Eric Schmitt. 2011. "US Expands its Drone War into Somalia." Accessed May 29, 2013. https://www.nytimes.com/2011/07/02/world/africa/02somalia.html

Menkhaus, Ken. 2002. "Political Islam in Somalia." Middle East Policy 9 (1): 109-23.

Menkhaus, Ken. 2007a. "Governance Without Government in Somalia: Spoilers, State Building, and the Politics of Coping." International Security 31 (3): 74-106.

Menkhaus, Ken. 2007b. "The Crisis in Somalia: Tragedy in Five Acts." African Affairs 106 (204): 357-390.

Møller, Bjørn. 2009. “Africa’s Sub-Regional Organizations: Seamless Web or Patchwork?” Crisis States Research Centre working papers series 2, 56. Crisis Research Centre, London School of Economics and Political Science, London, UK.

Mulugeta, Kidist. 2009. "The Role of Regional and International Organizations in Resolving the Somali Conflict: The Case of IGAD." Friedrick Ebert-Stiftung, Addis Ababa, December 2009.

Patrick, Stewart. 2007. “Failed' States and Global Security: Empirical Questions and Policy Dilemmas1." International Studies Review 9 (4): 644-62.

Pettiford, Lloyd. 1996. "Changing Conceptions of Security in the Third World." Third World Quarterly 17 (2): 289-306.

Powers, K., and G. Goertz. 2006. "The Evolution of Regional Economic Institutions (REI) into Security Institutions or The Demise of Realist Military Alliances?” Paper presented at Duke University Seminar on Global Governance and Democracy, Durham, NC, November 2006.

Prestholdt, Jeremy. 2011. "Kenya, the United States, and Counterterrorism.” Africa Today 57 (4): 2-27.

Shinn, David H. 2003. "Terrorism in East Africa and the Horn: An Overview." The Journal of Conflict Studies 23 (3).

Shinn, David H. 2005. "Ethiopia: Governance and Terrorism." In Battling Terrorism in East Africa, ed. Robert I. Rotberg. Washington, DC: Brookings Institute Press. Pp. 93-118.

Stewart-Ingersoll, Robert, and Derrick Frazier. 2012. Regional Powers and Security Orders: A Theoretical Framework. London: Routledge.

The Star. 2014. "Operation Linda Nchi Ends as African Union Takes over.” Accessed January 12, 2014. http://www.the-star.co.ke/news/article-25807/operation-linda-nchi-endsafrican-union-takes-over.

Thomas, Raju G.C. 2003. "What Is Third World Security?" Annual Review of Political Science 6 (1): 205-32. 
Tickner, Arlene. 2003. "Seeing IR Differently: Notes from the Third World." Millennium Journal of International Studies 32 (2): 295-324.

United Nations (UN). 2006. "Security Council Approves African Protection, Training Mission in Somalia, Unanimously Adopting Resolution 1725 (2006).” Accessed January 12, 2014. https://www.un.org/press/en/2006/sc8887.doc.htm

Woodward, Peter. 2006. Us Foreign Policy and East Africa. Hampshire, England: Ashgate Publishing, Ltd.

Funding details: The author did not receive any funding to conduct this research.

Disclosure statement: The author does not have any financial interest or benefit that has arisen from the direct applications of this research. 